\title{
CAREER MYTHS FROM STUDENTS AND EDUCATORS PERSPECTIVE
}

\author{
Agita Šmitiņa \\ Vidzeme University of Applied Sciences, Latvia
}

\begin{abstract}
Drastic and structural changes in the labour market and organizational environment related to the Covid-19 pandemic, rapid technological development, general globalization trends, demographic deterioration and other economic changes signal the need to find new approaches to the classical career management paradigm. Several studies on occupational segregation show that various stereotypes and misconceptions affecting the choice of occupations for young people are still relevant, but changes in the working environment also determine changes in this context. The European Social Fund project "Career Support in General and Vocational Education Institutions" has made huge contributions to the improvement of the career guidance system in Latvia since 2016, developing and approbating career development support action plans, along with informative and methodological materials, as well as educating career counsellors and support specialists, thereby updating their approaches to career guidance and management. This study analysed the views of students and educational staff about current beliefs and stereotypes about career choices and management.

Data from the 96 specialists and managers surveyed from different educational institutions reveal that educators have a strong belief in the importance of career stability. A majority believe that career choice is not always a guided process, although most support the involvement of career professionals. The importance of prestigious education and hard work, as well as success in one's career, is emphasized. The 10th through 12th grade students were surveyed in 2019-2020 in Daugavpils, Dobele, Ogre and Riga general educational schools. In the opinions of these pupils, there is evidence of various stereotypes regarding the choice of profession, as well as the correspondence of career beliefs and convictions within the dynamics of modern working life.
\end{abstract}

Keywords: Career choice, career education, career management, career myths, career beliefs.

\section{Introduction}

During this time of rapid and unpredictable changes in the labour market, economy, society and organizational environment in general, along with the current crisis caused by the Covid-19 pandemic, a new approach to the classical 
career management paradigm is necessary for most people who need to make choices and are at different stages of their career transition.

Although a number of important studies in the field of career development have been conducted in Latvia, researchers still point out that students and teachers typically have different understandings of the concept of career management. These differences also include different stereotypes, misconceptions and myths that relate to the old or traditional career management paradigm more than the new one, which is much more appropriate and flexible for meeting the modern conditions and new demands in the labour market.

The European Social Fund (ESF) project "Career Support in General and Vocational Education Institutions" (2016-2022) has been making a huge contribution to the improvement of Latvia's career guidance system and also the general comprehension of teachers and pupils about career choices and guidance. The main activities of the project are in the areas of developing and approbating career development plans, informational materials and methodological information and in educating career counsellors and support specialists to update their approaches to career guidance and management.

The aim of the present study was to investigate some of the most popular beliefs and myths about career choice and management from the perspective of both educators and school pupils. An online questionnaire was used to gather data from the educators, and a paper questionnaire was distributed to pupils in 10th through 12th grade classes.

\section{Career Management Paradigm: Traditional vs. New}

The leading scholars of traditional career development theories expect that young people will make a long-term career choice before graduating from high school, and they emphasize the vocational guidance model that explores one's interests, aptitudes and values, believing them to be essential for a good career choice. A successful choice of education is believed to be linked with a positive and stable vocational identity (Klimov, 1996). In the traditional career paradigm, the determination of a best-fit occupational goal by matching personal traits to job factors and long-term plans for career management was an essential part of career guidance (Savickas, 2005). In addition, the beliefs that the most important factor for career choice is stability, with minimal changes and transitions, and continuous acquisition of expert skills in one area are common in the traditional view and comprehension of individual career management (Bluestein, 2006).

However, new career paradigms began to develop in the 1990s, putting emphasis on an unrestricted career model. The main benefits offered are the acquisition of new knowledge and skills for self-improvement, increased personal contacts through meeting new people, personal growth, expansion of 
horizons through changing attitudes, skills for rapid transitions and improved communication skills, both oral and written (Arthur, 1999). These paradigms reflect a move from job stability to employability and from an organizational career to a career of change (Hall, 2002). The Covid-19 pandemic, along with a fast-growing technological innovation sector, globalization, unstable worldwide employment patterns and changes of personal and organizational values have determined transformations in organizational and personal beliefs, as well as in the skills of individuals (Orsmond, 2020; Deloitte, 2020). The changed nature of the work world means that individuals may have to revisit this process now and in the future more frequently than they did in the past. This includes the selfdevelopment process, which should now focus on short-term goals rather than long-term ones and taking control of one's personal development (Savickas, Baker, 2005).

The Organisation for Economic Co-operation and Development (OECD) released policy responses to Covid-19 surveys about job skills for mobilizing the workforce during the pandemic (OECD, 2020) that investigated the labour force's ability to meet immediate demands during the health crisis. The OECD described the most effective skills for successful transitions in the job market, emphasizing a variety of soft skills rather than professional skills in one career field.

\section{Career Beliefs and Myths}

Despite obvious changes in the understanding of career management, the well-developed career guidance systems in most countries and a wide variety of projects and activities in career education (e.g. ESF, 2016-2020), an approach based on the traditional career paradigm is still apparent. There are pervasive and persistent beliefs and myths among children, parents and teachers that are based on the foundations of a traditional understanding of career (Lemesonoka, 2020). Moreover, beliefs about traditional gender-role-oriented professional segregation are still found in some fields (LOPB, 2006; LIKTA, 2005; European Commission, 2009). Career beliefs are defined as positive and negative thoughts or assumptions people hold about themselves, occupations and the career development process (Sampson, Reardon, Peterson, Lenc, 2004). Career myths are incorrect assumptions and generalizations about the career counselling and decision-making process (Amundson, 1997). Career beliefs can influence a person's career-related aspirations and actions in both positive and negative ways. Negative beliefs can affect an individual's perception of themselves and the world of work, increasing the stress associated with making a career decision. They can also immobilize an individual's actions towards their career goals and create a belief that one is less able to make good career decisions 
(Sampson et al., 2004). Beliefs that previously served as legitimate guides to career development may no longer be viable in today's labour market (Roll, Arthur, 2002). Some authors have associated career myths with the concept of dysfunctional career thoughts (Sampson et al., 2004) and noted that dysfunctional thoughts and lack of development of career interests may be key factors in an inability to formulate educational and career goals and make appropriate career decisions (Railey, Peterson, 2000).

Career beliefs may carry over from childhood and family experiences, and they are connected to culture, religion, community and socio-economic conditions. They are also relatively strong, but several researchers have pointed out that career education activities, guidance (Peng, Herr, 1999) and counselling can change these beliefs (Roll, Arthur, 2002). Another factor is that some of the more ubiquitous career beliefs could be connected with cognitive biases or logical errors. For example, survivorship bias is the logical error of concentrating on the people or things that cleared some selection process in the past, which can lead to false conclusions or overly optimistic beliefs about career success because failures are ignored (Shermer, 2014).

Career misconceptions can be grouped according to Stead and Watson's (1993) Career Myths Scale (CMS), developed to assess the extent to which students subscribe to irrational beliefs regarding careers, using the following categories: 1) test myths, 2) misconceptions of exactitude, 3) self-esteem myths and 4) career anxiety myths (Stead, Watson, 1993). Career myths can be subdivided into different levels-individual, social and environmental/societal (Albien, Naidoo, 2017). Albien and Naidoo noted that the Stead and Watson's CMS is unable to capture many irrational career beliefs, especially at the social level. Therefore, they group social career beliefs in the categories of proficiency beliefs, common-practice beliefs, self-worth beliefs and persistence beliefs (Albien, Naidoo, 2017).

Career myths have been linked to the negative circumstances of career indecision (Saunders, Peterson, Sampson, Reardon, 2000) and increased negative emotions or lack of action towards making career decisions (Albien, Naidoo, 2017). However, positive career beliefs, such as self-efficacy, facilitate movement through career decision-making processes and can lead to career goal-related behaviour (Peterson et al., 1996).

Career myths persist among different groups of individuals, which is confirmed by many online career management portals regularly publishing refutations of various career myths and misconceptions. Additionally, myths are regularly discussed at various career events in schools and even universities.

Asking questions about different aspects of career development in order to identify the different misconceptions that are still pervasive, along with identifying beliefs and their potentially negative influences on career 
development, may provide sufficient insight for the generation of alternatives aimed at developing more effective career education programmes and improving career guidance systems at the state and local levels.

\section{Methodology}

The present study was carried out in two stages. For the ESF project 'Career Support in General and Vocational Education Institutions', 115 students in grades 10-12 from Daugavpils, Dobele, Ogre and Riga general educational schools $(56,5 \%$ girls, $n=65 ; 43,5 \%$ boys, $n=50)$ were surveyed in career education workshops from January to March 2020. The short questionnaire asked about popular myths about career stability, choice, goal setting, planning and success factors in career development (see Table 1 below). Career myths were categorized according to Albien and Naidoo's classifications (2017).

\section{Table 1 Statements about Career Choice: Student Questionnaire}

\begin{tabular}{ll}
\hline Career myths category & \multicolumn{1}{c}{ Statement } \\
\hline Proficiency beliefs & $\begin{array}{l}\text { 1) Success is a crucial element in career management. } \\
\text { 2) The most important thing in a career is the stability and } \\
\text { security of the profession. }\end{array}$ \\
$\begin{array}{l}\text { Persistence beliefs } \\
\text { Misconceptions of }\end{array}$ & $\begin{array}{l}\text { 3) A career choice is for life. } \\
\text { exactitude }\end{array}$ \\
Common-practice beliefs & $\begin{array}{l}\text { 4) High salary and prestige are the most important factors in } \\
\text { career choice. } \\
\text { 5) Everyone has the potential to succeed in their field and } \\
\text { overcome all obstacles. }\end{array}$ \\
\hline
\end{tabular}

Adapted from Albien and Naidoo (2017). 
Table 2 Statements about Career Choice: Educator Questionnaire

\begin{tabular}{ll}
\hline Career myths category & \multicolumn{1}{c}{ Statement } \\
\hline Proficiency beliefs & 1) Success is a crucial element in career management. \\
Common-practice beliefs & $\begin{array}{l}\text { 2) The most important thing in a career is the development of } \\
\text { specialized professional skills. }\end{array}$ \\
Persistence beliefs & 3) Higher education is a crucial factor in getting a high-paying job. \\
Misconceptions of & $\begin{array}{l}\text { 4) Education in art science is not a particularly serious career } \\
\text { choice. }\end{array}$ \\
Coxactitude & $\begin{array}{l}\text { 5) A prestigious school guarantees a better job and status in the } \\
\text { future. }\end{array}$ \\
Misconceptions of & $\begin{array}{l}\text { 6) It is not desirable to bring work home; home is a place to relax. } \\
\text { exactitude }\end{array}$ \\
Misconceptions of & $\begin{array}{l}\text { 7) Hobbies are leisure activities; they are not related to work. } \\
\text { exactitude }\end{array}$ \\
Self-worth beliefs & $\begin{array}{l}\text { 8) Starting a new career stage would mainly rely on previous } \\
\text { knowledge and skills. } \\
\text { 9) The most important thing in a career is the stability and security } \\
\text { of the profession. }\end{array}$ \\
Persistence beliefs & $\begin{array}{l}\text { 10) Career choices will often be decided on their own. } \\
\text { 11) High salary and prestige are the most important factors in career } \\
\text { choice. } \\
\text { 12) Everyone has the potential to overcome all obstacles and } \\
\text { succeed at the highest levels in their field. }\end{array}$ \\
\hline Common-practice beliefs
\end{tabular}

Adapted from Albien and Naidoo (2017).

\section{Findings and Discussion}

Table 3 summarizes the assessments of different career statements from the students' perspectives. The statements were chosen based on the most popular career myths in Latvia as described by Lemesonoka (2020). Five types of career myths were represented: common-practice (4), proficiency beliefs (1), misconceptions of exactitude (3), self-worth (5) and persistence beliefs (1), as described by Albien and Naidoo (2017). The results show that, overall, students are rather optimistic about their potential to succeed in their chosen fields (75,65\% agreed). However, they also believe that success is a very important factor in choosing a career path $(60,86 \%)$. 
SOCIETY. INTEGRATION. EDUCATION

Proceedings of the International Scientific Conference. Volume IV, May $28^{\text {th }}-29^{\text {th }}$, 2021. 190-200

Table 3 Career Statement Assessments (high school students)

\begin{tabular}{|c|c|c|c|c|}
\hline Statement & $\begin{array}{l}\text { Agree } \\
(\mathrm{N})\end{array}$ & $\begin{array}{c}\text { Agree } \\
(\%)\end{array}$ & $\begin{array}{l}\text { Disagree } \\
(\mathrm{N})\end{array}$ & $\begin{array}{c}\text { Disagree } \\
(\%)\end{array}$ \\
\hline $\begin{array}{l}\text { 1) Success is a crucial element in career } \\
\text { management. }\end{array}$ & 70 & 60,86 & 45 & 39,14 \\
\hline $\begin{array}{l}\text { 2) The most important thing in a career is } \\
\text { the stability and security of the profession. }\end{array}$ & 35 & 30,43 & 85 & 69,57 \\
\hline 3) A career choice is for life. & 15 & 13,04 & 100 & 86,96 \\
\hline $\begin{array}{l}\text { 4) High salary and prestige are the most } \\
\text { important factors in career choice. }\end{array}$ & 67 & 58,26 & 48 & 41,76 \\
\hline $\begin{array}{l}\text { 5) Everyone has the potential to overcome } \\
\text { all obstacles and succeed at the highest } \\
\text { levels in their field. }\end{array}$ & 87 & 75,65 & 28 & 24,35 \\
\hline
\end{tabular}

Different assessments were seen in the responses from students and teachers regarding persistence-oriented myths, such as the stability and security of a profession. In student assessments, the stability and long-term security of a profession was not a very important factor for career choice-only 30\% stated that they partially or totally agreed with that belief (Statement 9). This assessment can also be related to the rapid changes in society and the organizational and job environments due to rapid technological leaps causing many professions to change, disappear and re-emerge (Deloitte, 2020).

Also, different generational cohorts may have an impact on the assessment of these statements. Students generally belong to Generation Z, whose habits are associated with flexible adaptation to many situations, professional use of technology and greater flexibility in changing hobbies and, later, professions (Töröcsik, Kehl, Szücs, 2014.). The opposite picture is observed in the teacher survey (see Figure 1), where practice-oriented considerations are assessed as more positive. Stability and security in a profession (Statement 9) was highly valued by $65 \%$ of educators, and reliance on one's professional abilities in a future career (Statement 2) was positively assessed by $74 \%$ of the educators. 


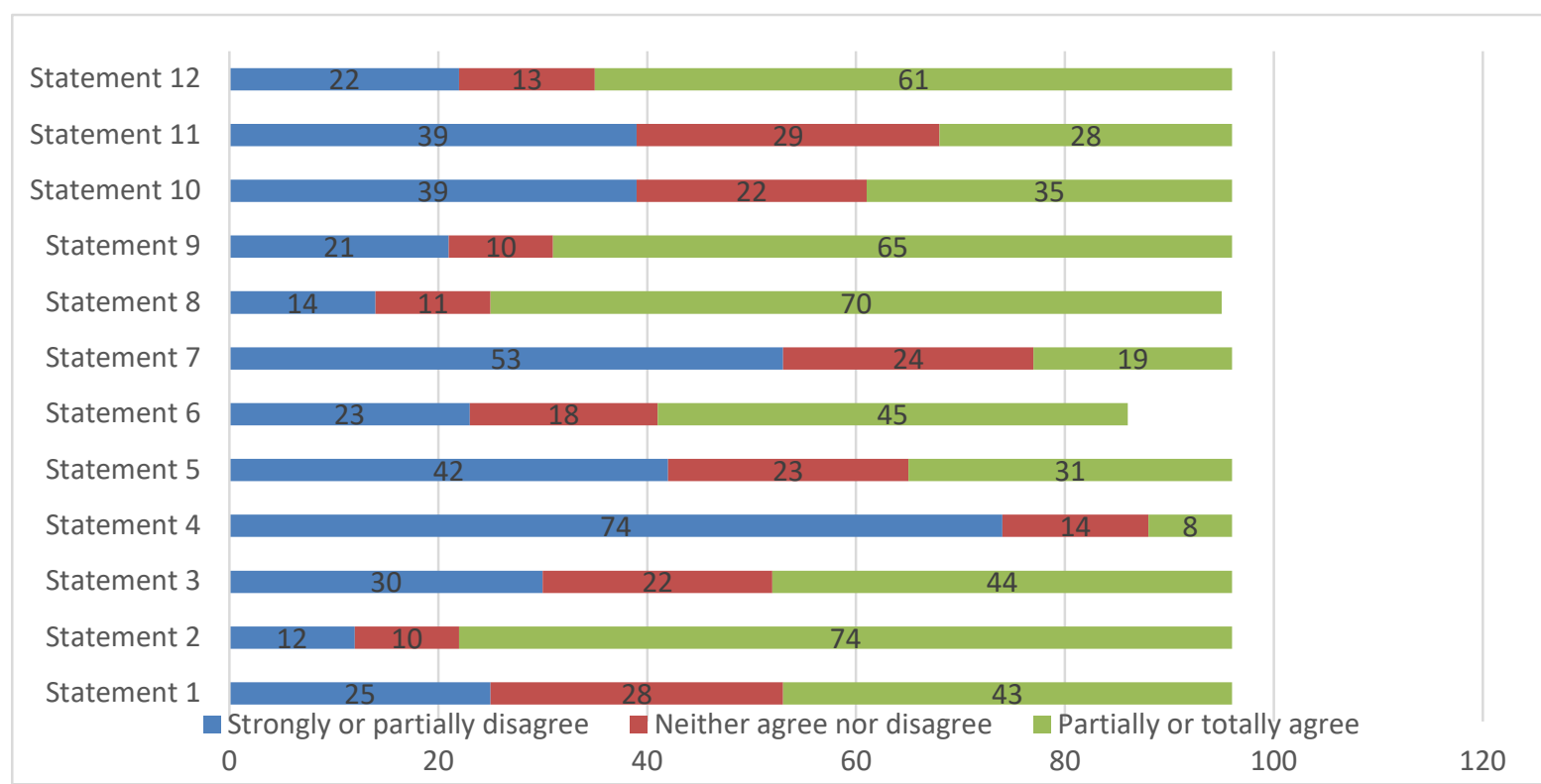

Figure 1 Career Statement Assessment (Educators, $n=115)$

A positive assessment of these claims may relate to the professional experience of teachers, as well as to the specificities of the age groups (most of the respondents were over 41 years old).

A recent OECD TALIS study on professional evaluations of teachers and school leaders (OECD, 2020) indicated that while only 23\% of educators in Latvia agreed that their profession is valued in society, teachers and school leaders are generally satisfied with their work and rely on their professional abilities as well as their ability to cooperate. The proficiency-based career myth assessment showed that educators rely less on the role of success in career leadership, but neither does it exclude this factor (43\% agree). Attitudes towards the second proficiency-based myth of this kind, that a career choice will be decided on its own (Statement 10), were divided-39\% did not support it, but $35 \%$ did. Successful career choice in both the traditional career paradigm and the new one is associated with informed career decision-making, where career support also plays an important role. Teachers are an essential element of a career guidance system, so such an assessment could signal that teachers might indicate to students they will find a future career path on their own, without special support or guidance.

Conversely, when students were asked about practice-oriented myths, such as the prestige of the profession and high salaries, 58\% supported statements that these factors are very important in career choice. Educators were less supportive (Statement 11) - only a third of respondents gave a positive evaluation of the statement. This may be explained by the lower levels of remuneration for the teaching profession along with other values inherent in the choice of the profession. 
Self-worth career myths that emphasize everyone's potential to achieve even the loftiest goals were very supported among students-almost $87 \%$ were confident about their ability to achieve the highest professional goals. Career theories play a very important role in setting career goals, but it is always noted that goals must be clear, achievable, time-based and measurable; otherwise, the goals may be unachieved, and the young person may not fulfil their dream. It is also necessary to take into account common cognitive errors such as the survival bias that means career objectives may not be achievable if you are focusing on only the top level of career achievement. However, teachers point out that it is very important to inspire young people by example and to allow them to believe in their abilities (Statement 12).

The survey also included statements related to misconceptions of exactitude myths. The statement that it is not desirable to combine work and home life was supported by $45 \%$ of professionals (Statement 6 ). This may be due to the survey of teachers being conducted in April and May of 2020, when the country and its labour market were under the restrictions imposed by the Covid-19 crisis and the emergency rules that affected teachers very directly, disrupting the balance of home and work life. It also revealed respondents' objective difficulties in accepting the situation of having to work from home, which fully reoriented their work. It is clear that educators value the role of higher education in career development- $44 \%$ of respondents indicated that higher education is a prerequisite for a good career and a high-paying job. However, this view is somewhat overturned by several studies on the factors that employers find important (Šmitina, 2018). Job surveys sometimes indicate that higher education is not always the most important factor allowing you to move up the career ladder.

\section{Summary and Conclusions}

Due to both the Covid-19 crisis and changes in general labour market trends, it is crucial to update the role of career planning and career education in career management processes. Recent changes show that people need to be immensely flexible in changing their persistent career beliefs and myths-when professions, employment and work enter the home environment, the required skills change rapidly. The younger generation bases their career choices on principles other than the traditional career paradigm, and this is not always consistent with the beliefs of career guidance professionals and educators.

The data obtained in the present study highlight these differences between student and educator beliefs about careers. Career security, reliance on certain professional abilities and a desire to not mix work with hobbies and home life are more important for educators. However, young people are confident in their 
ability to achieve their goals despite various barriers, without paying much attention to the stability and prestige of the profession. Instead, students prefer common-practice beliefs that are less important for already mature professionals. This study also highlights the importance of career management in secondary schools and the role of the teacher in this process. As the research data cannot be generalized to the entire population of educators and students, research on career myths and persistent stereotypes regarding career choices needs to be continued in more depth.

\section{References}

Anouk, J. Albien, Anthony, V. Naidoo. (2017). Deconstructing career myths and cultural stereotypes in a context of low resourced township communities. South African Journal of Education, Vol 37, No 4.

Arthur, M.B, Inkson, K., Pringle, J.K. (1999). The New Careers: Individual Action and Economic Change, 132-133. London: Sage Publications.

Bluestein, D. L. (2006). The psychology of working: A new perspective for career development, counselling, and public policy, 125-129. Mahwah, NJ: Lawrence Erlbaum.

Hall, D.T. (2002) Careers in and out of organizations. (24-28) London: Sage Publications.

Deloitte. (2020). Combating COvid-19 with an agile change management approach. Retrieved from https://www2.deloitte.com/content/dam/Deloitte/in/Documents/humancapital/in-hc-consulting-deloitte-change-management-pov-on-covid-noexp.pdf

European Comission. (2009). Gender segregationin the labour market Root causes, implications and policy responses in the EU. Retrieved from http://ec.europa.eu/progress, 2009

Klimov, E.A. (1996). Psihologija professionaljnovo samoopredelenija. Rostov: Fenikss.

Latvijas Organizāciju Psihologu biedrība. (2006). Pētījums par profesiju segregācijas cēloṇiem un stereotipiem. Pieejams: https://equal.sif.gov.lv/faili/rezultati /LOPB_kvantit_rezultati.pdf

Lemesonoka. (2020). Vecāku atbalsts bērnam veiksmīgas karjeras veidošanā. Rokasgrāmata skolotājiem un vecākiem. Rīga: Zvaigzne ABC

LIKTA. (2005). Projekts "Profesiju segregācijas cēloṇu mazināšana". Pieejams: https://equal.sif.gov.lv/faili/rezultati/Profesiju_segregacija_IKT_nozare.pdf

OECD. (2020). Policy Responses to Coronavirus (COVID-19). Skill measures to mobilise the workforce during the COVID-19 crisis. Retrieved from https://www.oecd.org/ coronavirus/policy-responses/skill-measures-to-mobilise-the-workforce-during-thecovid-19-crisis-afd33a65/

OECD. (2020). Teachers and School Leaders as Valued Professionals. Talis 2018 Results Volume II.

Orsmond, Q. (2020). COVID-19 and the Impact on Organisational Change. Retrieved from https://www.cmcpartnership.com/en-za/blog/covid-19-and-the-impact-onorganizational-change

Peng, H., Herr E. (1999). The Impact of Career Education Courses on Career Beliefs and Career Decision Making Among Business College Students in Taiwan. Journal of 
Career Development, Vol25, Issue 4, DOI: https://doi.org/10.1177/089484539902 500404

Peterson, G.W., et al. (1996). Becoming Career Problem Solvers and Decision Makers: A Cognitive Information Processing Approach. In Career Choice and Development, by D. Brown, L. Brooks, and Associates. San Francisco: Jossey-Bass.

Rayley, M. Peterson G. (2000). The Assessment of Dysfunctional Career Thoughts and Interest Structure Among Female Inmates and Probationers. Journal of Career Assesment, Vol 8, Issue 2, 119-129. DOI https://doi.org/10.1177/106907270000800202

Roll, T., Arthur, N. (2002). Beliefs in Career Counselling. University of Calgary. Retrieved from https://contactpoint.ca/wp-content/uploads/2013/01/pdf-02-03.pdf

Savickas, M. L., \& Baker, D. B. (2005). The history of vocational psychology: Antecedents, origins, and early development. In W. B. Walsh \& M. L. Savickas (Eds.), Handbook of vocational psychology (3rd ed.). Mahwah, NJ: Lawrence Erlbaum.

Sampson, J.P, Reardon, R.C., Peterson, G.W., Lenc, J.G. (2004). Career Counselling. Thomson Learning, Blemont, CA, USA.

Saunders, D.E., Peterson, G.W., Sampson, J.P., \& Reardon, R.C. (2000). Relation of Depression and Dysfunctional Career Thinking to Career Indecision. Journal of Vocational Behavior, Vol 56, Issue 2, pp 288-298.

Shermer, M. (2014). How the Survivor Bias Distorts Reality. Retrieved from https://www.scientificamerican.com/article/how-the-survivor-bias-distorts-reality/

Šmitina, A. (2018). Student Employability and Communication during the Job Recruitment Process: The Opinion of Students and Employers. Society, Integration, Education. Proceedings of the International Scientifical Conference, Rēzekne, 494-506.

Stead, G.B., Watson, M. (1993). The Career Myths Scale: its validity and applicability. International Journal for the Advancement of Counselling, volume 16, 89-97.

Törőcsik, M., Kehl, D., Szücs, K. (2014). How Generations Think: Research on Generation Z. Journal Acta Universitatis Sapientiae, Communicatio Scientia, Vol 1, 23-45. 